\title{
Implementation of Pre-Heating System in Stenters for Improving Machine Performance and Increasing Efficiency
}

\author{
Sk. Mohammad Raafi ${ }^{1}$ (i), Ummul Khair Fatema ${ }^{2}$ \\ ${ }^{1}$ Department of Wet Process Engineering, Bangladesh University of Textiles, Dhaka, Bangladesh \\ ${ }^{2}$ Department of Environmental Science and Engineering, Bangladesh University of Textiles, Dhaka, Bangladesh \\ Email: raafiwpe@gmail.com,ummuljp@gmail.com
}

How to cite this paper: Raafi, S.M. and Fatema, U.K. (2021) Implementation of PreHeating System in Stenters for Improving Machine Performance and Increasing Efficiency. Journal of Textile Science and Technology, 7, 143-151.

https://doi.org/10.4236/jtst.2021.74012

Received: August 3, 2021

Accepted: September 19, 2021

Published: September 22, 2021

Copyright $\odot 2021$ by author(s) and Scientific Research Publishing Inc. This work is licensed under the Creative Commons Attribution International License (CC BY 4.0).

http://creativecommons.org/licenses/by/4.0/

\begin{abstract}
In textile finishing, stenters always draw considerable attention to newer inventions to boost up production via maximum utilization of energy. Prior to main drying or heat-setting chambers, intermediate heating of cylindrical system especially by steam has a direct blessing to moisture evaporation, processing speed, fabric quality and so on. Based on actual operational data, this study reveals the outcomes of a pre-heating module installed within a stenter. After employing the pre-heating system to knit fabrics of different structures and compositions, $23 \%-61 \%$ moisture reduction was found and the speed of processing fabrics was increased simultaneously by $17 \%-30 \%$ without any compromise on fabric quality. Moreover, no less than $8.21 \%$ savings in annual electricity consumption were observed.
\end{abstract}

\section{Keywords}

Stenter, Pre-Heating, Machine Performance, Fabric Processing Speed, Energy Savings

\section{Introduction}

Synthetic fibers of polyamide, polyester and polyurethane origin mostly cause dimensional changes of subsequently produced pure or blended fabrics upon wet treatments, mostly due to the relaxation of filament tension. Thus, to control the desired fabric properties like width, weight per unit area (G.S.M.), shrinkage, etc. the internal molecular arrangements of those fibers are thermally stabilized and distributed to stress-free positions which are commonly known as "heat-setting" [1] [2] [3]. Alongside encountering weft distortion and relaxation of knit- 
ted loops, all of the wet cellulosic fabrics, man-made textiles and blended or synthetic fabrics are needed to dry and must conform to a certain tolerance level of finished fabric requirements [4]. Wet cellulosic fabrics have been found with increased drying time as they are generally hygroscopic in nature and hold a significant amount of bound moisture. Unbound (free) moisture can be assumed for the synthetics like polyester fabrics which lead to shorter drying times [5]. Typical stretched dryers or stenters are used to cater a variety of services including heat setting \& drying of open-width fabrics, moisture management, dimensional control, application of finishing chemicals, shade controlling, etc [6]. Depending on the fabric structure, exposure time, risk of damage, etc. factors, the drying of fabric is mainly performed around $150^{\circ} \mathrm{C}$ to $160^{\circ} \mathrm{C}$; where the temperature of heat-setting of blended or synthetic fabrics could be synchronized up to $220^{\circ} \mathrm{C}$ [7]. Since hot air is circulated to achieve these desire properties, indirect steam or thermo-heated oil or direct gas heating modes have been applied. Hot-oil and gas-fired stenters are commonly preferred over steam-driven stenters in terms of advantages and efficiency [8]. Mechanical pre-drying is regarded as one of the energy-efficient measures of textile wet processing [9]. During pre-heating/drying, the evaporated water from the fabric surface is carried out to the surrounding air via a diffusion mechanism [5]. Though mechanical de-watering is much economical than pre-drying using heat, the remaining moisture regain is comparatively higher in case of mechanical means since much of the residual water creates chemical bonding with fiber. Therefore, focusing on the drying economy with lowered moisture regain, thermal means like "conduction drying" was introduced where the open-width fabric is allowed to slide over some limited number of rotating heated metallic cylinders which are placed just after the mechanical moisture removing arrangement like finishing padder [10] [11]. Despite the desired high rate of heat transfer from the hot cylinder surface to the surface of contact fabric, the risk of distortion of delicate fabric surface and unwanted consequence produced by adherence of heat-transferred materials in different portions within fabric drew special attention [11]. Also, as the fabric is simultaneously needed to show plastic nature to achieve desired dimensional stability so the fabric should not be too dried in the cylinders [12]. Regarding these issues, the present work has been concentrated on the latest and highly developed pre-heating modules that are smoothly operated in the experimental case of the study.

\section{System Description}

The study has been conducted in a Bangladeshi knit composite industry having daily finishing capacity of 42 tons. The finishing line is equipped with five (5) stenters from renowned manufacturers. Mixture of hot combustion gases of the burner and recirculating air is responsible for preparing the heated air for drying and the temperature can be adjusted from $100^{\circ} \mathrm{C}$ to $220^{\circ} \mathrm{C}$.

Three (3) of the existing stenters of that factory are incorporated with preheating modules (Table 1). After fabric inlet, guide rollers, tension rollers, wash- 
ing/chemical tanks and finishing padder, the corrosion resistant pre-heating cylinders are placed in the production line. Two pre-heating systems are horizontally installed and the rest is vertically mounted (Figure 1). Both front and back sides of the fabric are evenly passed over the hot cylinders and reach the main chambers after the "straightening" arrangement. Additional utilities (steam, electricity etc.) are linked to the pre-heating system for level performance. The mechanical speed of the cylinders is properly synchronized with the speed of stenter.

\section{Experimental}

Six (6) different types of knit fabrics were selected to undergo two distinct frequent operations namely heat-setting and drying (Table 2, Table 3). During experimentation at the industry, the temperature and the relative humidity of the surrounding environment were measured $33^{\circ} \mathrm{C} \pm 1^{\circ} \mathrm{C}$ and $50 \% \pm 4 \%$ respectively with the help of wet-and-dry bulb hygrometer.

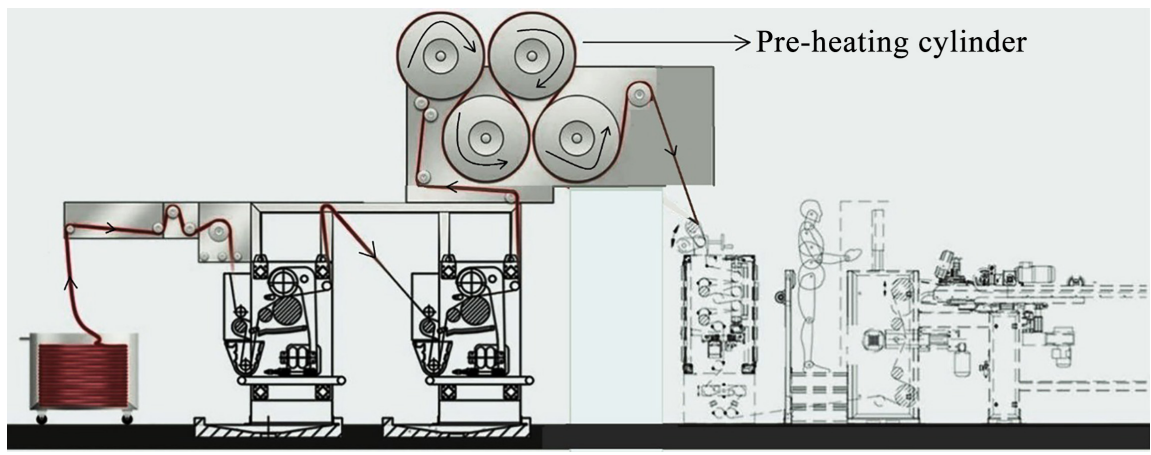

(a)

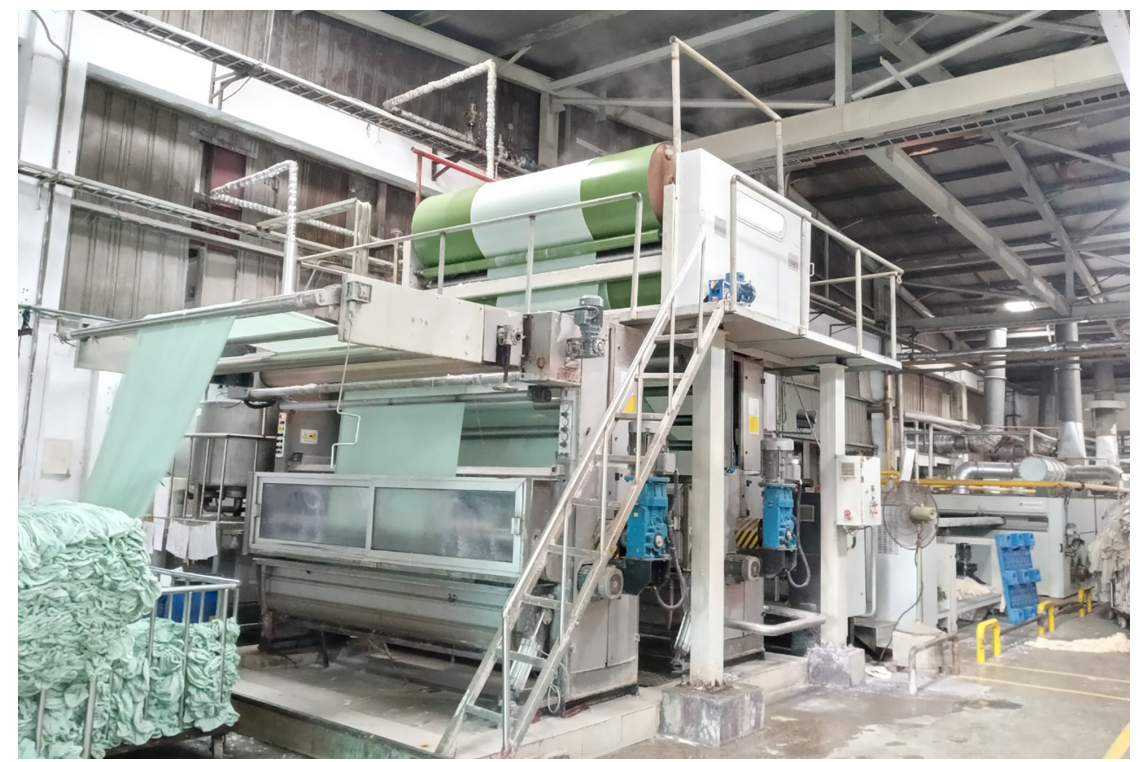

(b)

Figure 1. View of vertically-mounted pre-heating system in stenter ((a) Schematic passage diagram of fabric through pre-heating cylinders; (b) Actual scenario in the industry). 
Table 1. Technical specifications of pre-heating system.

\begin{tabular}{cc}
\hline Parameter & Value \\
\hline No. of pre-heating cylinders & 4 \\
Working width & $1600-3800 \mathrm{~mm}$ \\
Structure of cylinders & Teflon coated stainless steel \\
Diameter of each cylinder & $640 \mathrm{~mm}$ \\
Heating medium & Steam \\
Maximum operating temperature & $120^{\circ} \mathrm{C}$ \\
Total steam consumption & $129-147 \mathrm{~kg} / \mathrm{h}$ (considering $2500 \mathrm{~mm}$ working width) \\
Total electricity consumption & $2.8 \mathrm{KW} / \mathrm{h}$ \\
Durability & 20 years $(\mathrm{minimum})$ \\
\hline
\end{tabular}

Table 2. Description of samples for heat-setting.

\begin{tabular}{|c|c|c|c|c|c|c|c|c|c|c|}
\hline \multirow{2}{*}{$\begin{array}{l}\text { Sample } \\
\text { ID }\end{array}$} & \multirow{2}{*}{$\begin{array}{l}\text { Fabric } \\
\text { Type }\end{array}$} & \multirow[t]{2}{*}{ Composition } & \multirow{2}{*}{$\begin{array}{c}\text { Feed } \\
\text { Width } \\
\text { (inches) }\end{array}$} & \multirow{2}{*}{$\begin{array}{c}\text { Feed } \\
\text { G.S.M. }\end{array}$} & \multicolumn{2}{|c|}{$\begin{array}{l}\text { Padder pressure } \\
\text { (bar) }\end{array}$} & \multirow{2}{*}{$\begin{array}{l}\text { Pre-heating } \\
\text { Temperature } \\
\left({ }^{\circ} \mathrm{C}\right)\end{array}$} & \multirow{2}{*}{$\begin{array}{c}\text { Chamber } \\
\text { Temperature } \\
\left({ }^{\circ} \mathrm{C}\right)\end{array}$} & \multirow{2}{*}{$\begin{array}{l}\text { Finished } \\
\text { Width } \\
\text { (inches) }\end{array}$} & \multirow{2}{*}{$\begin{array}{l}\text { Finished } \\
\text { G.S.M. }\end{array}$} \\
\hline & & & & & $1^{\text {st }}$ & $2^{\text {nd }}$ & & & & \\
\hline H-1 & $\begin{array}{l}\text { Single } \\
\text { jersey }\end{array}$ & $\begin{array}{c}95 \% \text { cotton }(34 \mathrm{Ne}) \\
5 \% \text { elastane }\end{array}$ & 84 & 195 & 3.5 & 4 & 105 & 205 & 89 & 155 \\
\hline $\mathrm{H}-2$ & $\begin{array}{l}\text { Single } \\
\text { jersey }\end{array}$ & $\begin{array}{l}60 \% \text { cotton }(34 \mathrm{Ne}), \\
40 \% \text { polyester with } \\
\text { elastane }\end{array}$ & 76 & 230 & 3.5 & 4 & 105 & 200 & 81 & 146 \\
\hline $\mathrm{H}-3$ & $1 \times 1 \mathrm{Rib}$ & $\begin{array}{c}95 \% \text { BCI cotton } \\
(34 \mathrm{Ne}), 5 \% \text { viscose } \\
\text { with elastane }\end{array}$ & 72 & 314 & 3 & 4 & 105 & 205 & 78 & 210 \\
\hline
\end{tabular}

Table 3. Description of samples for drying.

\begin{tabular}{|c|c|c|c|c|c|c|c|c|c|c|}
\hline \multirow{2}{*}{$\begin{array}{l}\text { Sample } \\
\text { ID }\end{array}$} & \multirow{2}{*}{$\begin{array}{l}\text { Fabric } \\
\text { type }\end{array}$} & \multirow[t]{2}{*}{ Composition } & \multirow{2}{*}{$\begin{array}{c}\text { Feed } \\
\text { width } \\
\text { (inches) }\end{array}$} & \multirow{2}{*}{$\begin{array}{c}\text { Feed } \\
\text { G.S.M. }\end{array}$} & \multicolumn{2}{|c|}{$\begin{array}{c}\text { Padder pressure } \\
\text { (bar) }\end{array}$} & \multirow{2}{*}{$\begin{array}{l}\text { Pre-heating } \\
\text { temperature } \\
\left({ }^{\circ} \mathrm{C}\right)\end{array}$} & \multirow{2}{*}{$\begin{array}{c}\text { Chamber } \\
\text { temperature } \\
\left({ }^{\circ} \mathrm{C}\right)\end{array}$} & \multirow{2}{*}{$\begin{array}{c}\text { Finished } \\
\text { width } \\
\text { (inches) }\end{array}$} & \multirow{2}{*}{$\begin{array}{l}\text { Finished } \\
\text { G.S.M. }\end{array}$} \\
\hline & & & & & $1^{\text {st }}$ & $2^{\text {nd }}$ & & & & \\
\hline D-1 & $\begin{array}{l}\text { Single } \\
\text { jersey }\end{array}$ & $\begin{array}{c}100 \% \text { PSCP } \\
\text { cotton }(26 \mathrm{Ne})\end{array}$ & 64 & 154 & 3.5 & 2 & 100 & 140 & 69 & 150 \\
\hline D-2 & $1 \times 1 \mathrm{rib}$ & $\begin{array}{c}97 \% \text { BCI cotton } \\
(34 \mathrm{Ne}), 3 \% \text { elastane }\end{array}$ & 70 & 190 & 3.5 & 2.5 & 103 & 150 & 75 & 172 \\
\hline D-3 & $\begin{array}{l}\text { Diagonal } \\
\text { terry }\end{array}$ & $\begin{array}{c}60 \% \text { cotton } \\
(20 \mathrm{Ne}+34 \mathrm{Ne}) \\
40 \% \text { polyester }(75 \mathrm{D})\end{array}$ & 64 & 232 & 3.5 & 2.5 & 100 & 140 & 80 & 199 \\
\hline
\end{tabular}

For both heat-setting and drying, the fabric passage was same. The fabric was carried over feed rollers to 1st padder where the pressure was set to 3 - 3.5 bar. Then, the squeezed fabric was immersed in $2^{\text {nd }}$ tank and the set pressure in $2^{\text {nd }}$ padder was 2 - 4 bar depending on the operation (heat-setting/ drying). After that, the fabric was conveyed to pre-heating cylinders. Active pre-heating tem- 
perature was $100^{\circ} \mathrm{C}-105^{\circ} \mathrm{C}$. For comparison and evaluation of the results, fabrics free from processing through pre-heating section were examined also.

After passing the pre-heating section, the fabric was directed to main hot chambers of the stenter. Heat setting temperature was chosen above the glass transition temperature and at a time below the melting temperature of elastane. All the stenters which were taken into account had 8 (eight) chambers with $3 \mathrm{~m}$ chamber length in each, and every chamber was equipped with 4 (four) pieces of air-circulating fans. There were two exhausts in each of them; the initial exhaust was connected to the first four chambers where the evaporation rate is comparatively higher than the latter exhaust covering the last four chambers.

\subsection{Moisture Regain Analysis}

Upon absorbing moisture, fiber gets swelled and the cross-sectional area is changed. So, any change in the volume of a material significantly affects its mass. Moisture regain $\left(M_{r}\right)$ can be defined as the ratio of the mass of water present $(W)$ in the material to the oven dry mass $(D)$ of the material, expressed in percentage (Equation (1)) [13]:

$$
\text { Moisture regain }\left(M_{r}\right)=\frac{\text { Mass of water contained }(W)}{\text { Oven dry mass }(D)} \times 100 \%
$$

The standard testing atmosphere is $65 \% \pm 2 \% \mathrm{RH}$ and $27^{\circ} \mathrm{C} \pm 2{ }^{\circ} \mathrm{C}$. Oven drying was carried out at $105^{\circ} \mathrm{C} \pm 2{ }^{\circ} \mathrm{C}$ temperature after conditioning the samples at room temperature for certain times.

\subsection{Production Capacity Assessment}

The production (in unit "kg/hr") of a stenter is determined by Fabric speed or running length of fabric per unit time. The higher the speed of fabric processing, the greater the production capacity (Equation (2)). Also, there exists relation between mechanical speed of fabric and dwell time. The dwell time of fabric in stenter is inversely proportional to fabric speed when the length of each chamber and total no. of chambers in stenter are constant (Equation (3)). Any increase in production speed decreases the dwell time in turns; so, greater amount of fabric can be finished via stenter at the same interval.

$$
\begin{aligned}
& \text { Production capacity }(\mathrm{kg} / \mathrm{hr})= \\
& \frac{\text { Fabric speed }(\mathrm{m} / \mathrm{min}) \times \text { Fabric width }(\text { inches }) \times \text { G.S.M. } \times 60 \times \text { Efficiency }}{39.37 \times 1000}
\end{aligned}
$$

$$
\text { Dwell time }(\mathrm{sec})=\frac{\text { Number of chambers } \times \text { Chamber length }(\mathrm{m}) \times 60}{\text { Fabric speed }(\mathrm{m} / \mathrm{min})}
$$

\section{Results and Discussion}

\subsection{Effects of Moisture Evaporation}

The reduction moisture regain of wet fabrics regarding the successive stages of operation including the pre-heating system is illustrated in Figure 2. 


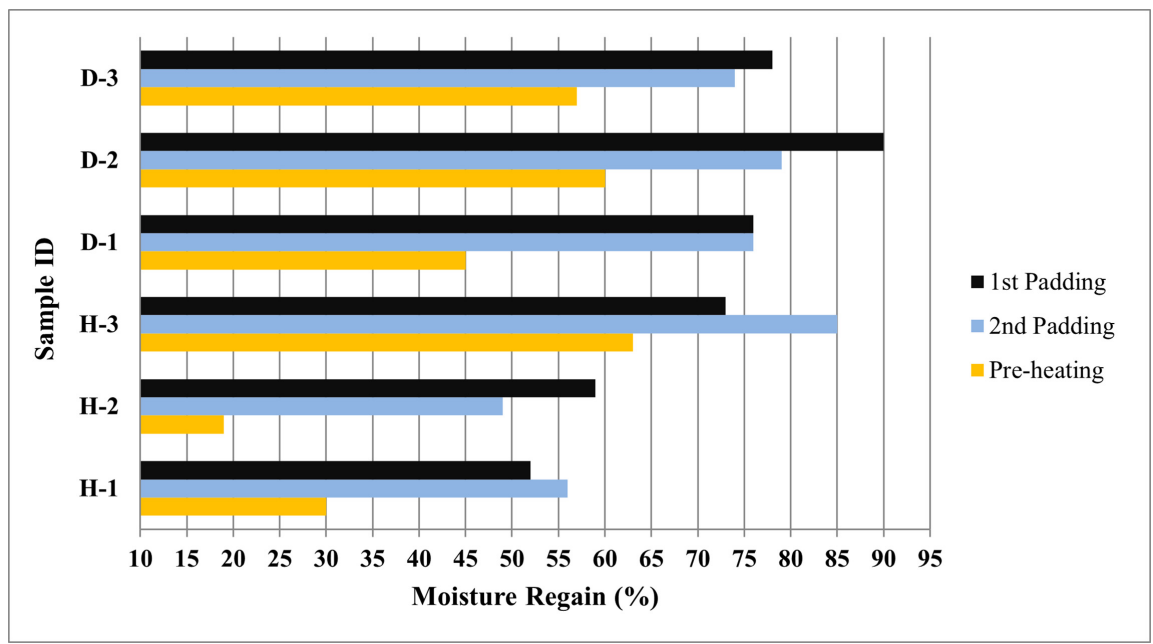

Figure 2. Effects of moisture evaporation of fabrics considering moisture regain just after successive operations.

Figure 2 interprets that, all of the samples have proven to drop the moisture regain significantly when pre-heated in $100^{\circ} \mathrm{C}-105^{\circ} \mathrm{C}$. The $\mathrm{H}-2$ sample that means, 60/40 CVC single jersey fabric has shown less moisture regain compared to the rest heat-set samples containing elastane and dominant cotton. The fact behind this is polyester is least hydrophilic. In case of samples $\mathrm{H}-1$ and $\mathrm{H}-2$, the hydrophobic oils are removed after $1^{\text {st }}$ padding therefore, the hygroscopic nature of them is found to be improved despite comparatively greater pressure in the $2^{\text {nd }}$ padder. The presence of higher moisture absorbent viscose fiber in sample $\mathrm{H}-3$ has also contributed to its greater moisture regain. Compared to $2^{\text {nd }}$ padding, about $46 \%, 61 \%$ and $26 \%$ moisture have been found to evaporate from $\mathrm{H}-1, \mathrm{H}-2$ and $\mathrm{H}-3$ samples respectively when they passed the pre-heating cylinders. The quality of the heat-set fabrics of $\mathrm{H}-1$ and $\mathrm{H}-2$ didn't fall even after processing with $30 \%$ and $19 \%$ residual moisture regain respectively. If the heat-set samples were directly exposed to highly hot temperatures of main chambers of the stenter without passing through the pre-heating system, there might introduce the risk of damaging of the elastane surface because of the heat shock of molecular chain.

Before drying, the pre-treated/dyed fabrics are softened mostly, maintaining a certain pick-up level. D-1 sample was made of $100 \%$ cotton and its regain after $2^{\text {nd }}$ padding (at 2 bar pressure) has been found equal to that after $1^{\text {st }}$ padding. Since, elastane has better moisture regain than polyester so D-3 has displayed comparatively low regain than D-2 when both are subjected to 2.5 bar pressure of the second padder. With reference to $2^{\text {nd }}$ padding, approximately $41 \%, 24 \%$ and $23 \%$ reduction in moisture regain have been calculated for D-1, D-2 and D-3 samples respectively.

\subsection{Effects of Fabric Processing Speed}

To attain the finished fabric requirements, the variation in fabric processing speed in stenter regarding the situation of operation is demonstrated in Figure 3. 


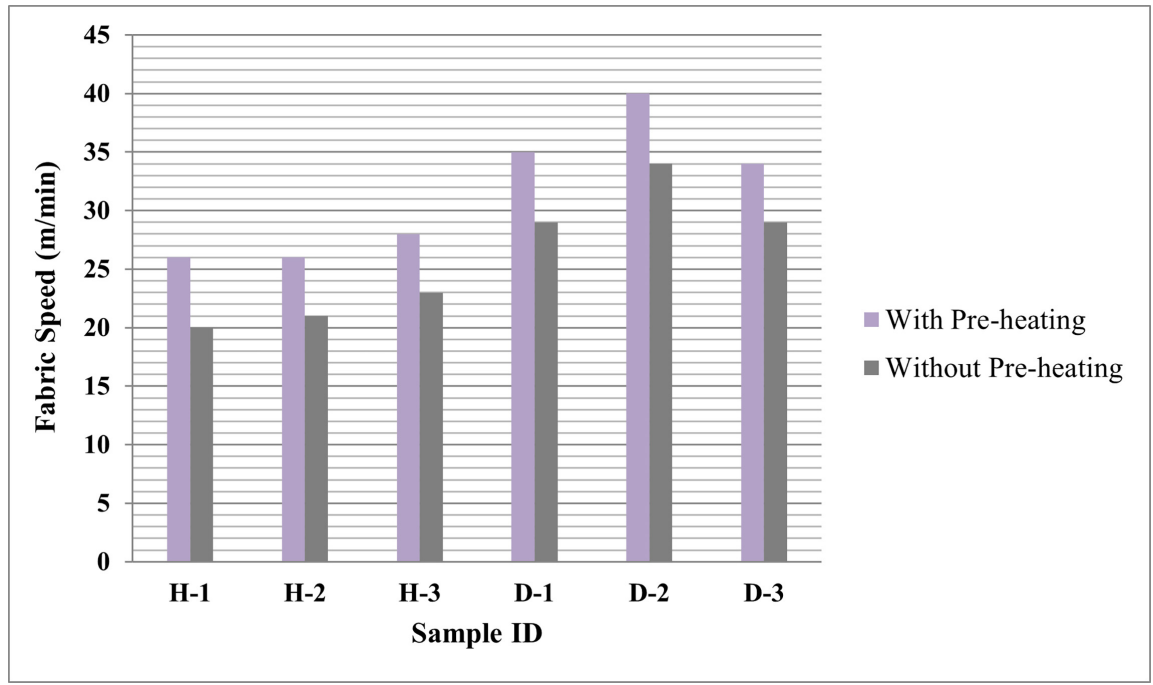

Figure 3. Effects of fabric processing speed of stenter at different operational conditions.

Table 4. Comparison of electricity consumption of stenter at different operational conditions.

\begin{tabular}{ccccc}
\hline $\begin{array}{c}\text { Average production, } \\
\boldsymbol{P}_{\boldsymbol{A}}(\mathrm{Kg} / \text { stenter/day) }\end{array}$ & Operating condition & $\begin{array}{c}\text { Time required to } \\
\text { achieve } \boldsymbol{P}_{\boldsymbol{A}} \text { (Hours) }\end{array}$ & $\begin{array}{c}\text { Electricity } \\
\text { consumption }(\mathrm{KW} / \mathrm{h})\end{array}$ & $\begin{array}{c}\text { Annual electricity } \\
\text { consumption }(\mathrm{KW})\end{array}$ \\
\hline \multirow{2}{*}{9000} & Stenter without pre-heating module & 24 & 37.5 & $280,800.00$ \\
& Stenter with pre-heating module & 20.5 & 40.3 & $257,758.80$ \\
\hline
\end{tabular}

Figure 3 reveals that, the mechanical speed of the stenter that is, the speed of processing fabrics has eventually increased when the pre-heating using steam was brought in action. Pre-heating lessens the load of main chambers by gradual heating and then transporting the fabric in warm, moist condition. The increase of speeds in pre-heated operation have been measured as around $30 \%, 24 \%$, $22 \%, 21 \%, 18 \%$ and $17 \%$ for $\mathrm{H}-1, \mathrm{H}-2, \mathrm{H}-3, \mathrm{D}-1, \mathrm{D}-2$ and $\mathrm{D}-3$ samples respectively. Because of reduction in dwell time and increase in processing speed, the production capacity of that facility was remarkably increased.

\subsection{Energy Savings}

The comparative annual savings in electrical energy achievable by implementing pre-heating system in stenter is represented via Table 4 where the required time to meet daily average production $\left(P_{A}\right)$ is calculated based on minimum increase in fabric processing speed that has been proven earlier in section 4.2.

Table 4 points out that, despite consuming additional $2.8 \mathrm{KW} / \mathrm{h}$ electrical energy to operate the pre-heating module, the daily run-time savings of 3.5 hours obtained from a stenter has contributed to an $8.21 \%$ reduction in annual electricity consumption. Thus, alongside with rising in energy efficiency, financial competitive advantages can easily be achieved.

\section{Conclusion}

Investigation of the consequences of integrating pre-heating system in stenter 
has been performed in this study. Well-installed pre-heating module has been proven to increase the throughput of the existing facility to at least $17 \%$ with sufficient moisture management. However, fabrics having below 62 inches width may impose problems in controlling dimensional stability due to the instant relaxation in pre-heating cylinders, so this should be carefully considered. Since this module can be additionally installed to the stenters, synchronization of motion between them is another key aspect; even a slight change may affect fabric tension or cause tearing. Also, to maintain a comfortable working environment, proper ventilation should be ensured. In the future, the performance of pre-heating systems driven by other mechanisms like thermo-oil, infra-red, fully electric, etc., can be analyzed for comparison. Steps might be taken to develop the cylindrical structure. Besides, assessment of a hot-oil-based stenter introduced with the same steam pre-heating system (as of this study) can be evaluated.

\section{Acknowledgements}

The authors would like to express gratitude to the management of Fakir Knitwears Ltd., Narayangonj, Bangladesh for providing administrative support to study on the stenters.

\section{Conflicts of Interest}

The authors declare no conflicts of interest regarding the publication of this paper.

\section{References}

[1] Senthilkumar, M., Sounderraj, S. and Anbumani, N. (2012) Effect of Spandex Input Tension, Spandex Linear Density and Cotton Yarn Loop Length on Dynamic Elastic Behavior of Cotton/Spandex Knitted Fabrics. Journal of Textile and Apparel, Technology and Management, 7, 1-16.

[2] Makhlouf, C., Ladhari, N., Braham, D., Roudesli, S. and Sakly, F. (2014) The Effect of Hot Water Setting Treatment on the Dyeing Properties of Grafted Polyamide 6.6 Microfibres. The Journal of the Textile Institute, 106, 986-994. https://doi.org/10.1080/00405000.2014.958297

[3] Rath, J.P., Chaki, T.K. and Khastgir, D. (2011) Effect of Thermal Treatment on Structure and Properties of Polyester Tire Cords. Journal of Applied Polymer Science, 124, 266-274. https://doi.org/10.1002/app.34363

[4] Onal, L. and Candan, C. (2003) Contribution of Fabric Characteristics and Laundering to Shrinkage of Weft Knitted Fabrics. Textile Research Journal, 73, 187-191. https://doi.org/10.1177/004051750307300301

[5] Cay, A., Gurlek, G. and Oglakcioglu, N. (2017) Analysis and Modeling of Drying Behavior of Knitted Textile Materials. Drying Technology, 35, 509-521. https://doi.org/10.1080/07373937.2016.1192190

[6] Akan, A.E. and Ünal, F. (2020) Thin-Layer Drying Modeling in the Hot Oil-Heated Stenter. International Journal of Thermophysics, 41, Article No. 114. https://doi.org/10.1007/s10765-020-02692-x

[7] Cay, A., Tarakçioğlu, I. and Hepbasli, A. (2010) Exergetic Analysis of Textile Convective Drying with Stenters by Subsystem Models: Part 2-Parametric Study on 
Exergy Analysis. Drying Technology, 28, 1368-1376.

https://doi.org/10.1080/07373937.2010.482696

[8] Cay, A., Tarakçıŏlu, I. and Hepbasli, A. (2007) Exergetic Performance Assessment of a Stenter System in a Textile Finishing Mill. International Journal of Energy Research, 31, 1251-1265. https://doi.org/10.1002/er.1295

[9] Hasanbeigi, A. and Price, L. (2012) A Review of Energy Use and Energy Efficiency Technologies for the Textile Industry. Renewable and Sustainable Energy Reviews, 16, 3648-3665. https://doi.org/10.1016/j.rser.2012.03.029

[10] Lee, H.S., Carr, W. and Ok, H. (2006) Drying of Textile Products. In: Mujumdar, A.S., ed., Handbook of Industrial Drying, 3rd Edition, CRC Press, Boca Raton.

[11] Uthwatt, T.A. and Woollatt, J.S. (1959) Stenter Drying. Journal of the Society of Dyers and Colourists, 75, 445-451. https://doi.org/10.1111/j.1478-4408.1959.tb02340.x

[12] Islam, S., Alam, S.M. and Akter, S. (2018) Identifying a Suitable Heat Setting Temperature to Optimize the Elastic Performances of Cotton Spandex Woven Fabric. Research Journal of Textile and Apparel, 22, 260-270.

https://doi.org/10.1108/RJTA-01-2018-0002

[13] Saville, B.P. (1999) Physical Testing of Textiles. Woodhead Publishing, Sawston. 